\title{
Additional contributors
}

Ariane Agunsoye, Lecturer in Economics, Goldsmiths, University of London, UK

Michelle Groenewald, Lecturer in Economics, North-West University, South Africa

Danielle Guizzo, Senior Lecturer in Economics, University of Bristol, UK

Kamal Ramburuth-Hurt, Student, Masters in Economic Policy and Analysis, Sorbonne Université, France

Francesa Rhys-Williams, Economist, Ministry of Justice, UK

Bruno Roberts-Dear, Policy Advisor, HM Treasury, UK

Brototi Roy, Postdoctoral Researcher, Institute of Development Policy, University of Antwerp, Belgium 